\title{
The Simulacra of Responsibility? The Efficiency of Global CSR Policies in CEE Countries: The Case Study of a Chemical MNE
}

DOI: http://dx.doi.org/10.12775/JCRL.2019.008

\author{
JOANNA SZYMONEK \\ Jagiellonian University, Krakow, Poland \\ e-mail: joanna.szymonek@gmail.com
}

\begin{abstract}
The aim: The paper discusses global CSR policies applied by multinational companies as well as identifies existing differences in the approaches to CSR presented by multinational enterprises (MNEs) in their headquarters and foreign subsidiaries located in the CEE region. The study concentrates on the labour perspective, as labour costs and access to qualified workforce are claimed to be determinants of the investment's location.
\end{abstract}

Methodology: The qualitative single case study methodology was applied. A MNE of Japanese origin operating in the chemical industry and its Polish subsidiaries were the units of analysis.

Main findings: The study shows that the headquarters seem to be much more advanced in CSR than foreign subsidiaries. Some discrepancy between declaration and practice has been noticed from the Polish labour viewpoint. This may be associated with the style of diffusion of practices in industrial relations and HRM, and may create only a specific simulacrum of social responsibility. Also, the asymmetry in quality of information on CSR policies implemented in the parent company was observed what may affect the transparency of a whole group.

Implication for further research: Exploration of other major competitors originating from other countries, operating in Poland, possessing significant market shares could help to reveal the level of advancement and presence of self-regulatory CSR mechanisms supporting the creation 
of local CSR approaches in the Polish subsidiaries of MNEs in the chemical industry. It could also reflect the trade union capacity in use of CSR tools for social monitoring of human and trade union rights at the workplace and their interests in contribution to building more sustainable workplace.

Keywords: CSR policies, multinational enterprises, simulacrum, labour.

\section{Introduction}

In the modern world economy, a popular statement describing multinational enterprises (MNEs) as primary movers and shapers of economy (Dicken, 2003) is difficult to be questioned. Although foreign direct investments (FDIs) and associated with them MNEs in their business expansion play an important role in the economic development especially in the case of transition economies through transferring knowledge and managerial practices to new markets (Enderwick, 2005), they are also responsible for some environmental and social damages revealing weak and malfunctioning corporate governance structures. The compliance misconducts entail the need for greater transparency and more responsible business behaviours, mostly expressed in corporate social responsibility (CSR) practices pursued by particular companies. For the purpose of this paper the definition of CSR introduced by the European Commission will be adopted, which states that corporate social responsibility is "the responsibility of the enterprises for their impact on society” (European Commission, 2011). The effectiveness of mentioned above policies has been understood as a reduction of a negative impact and boosting a positive impact, with compliance with the local and international regulations as a prerequisite. One of the major problem emerging in the area of CSR tends to be the asymmetry between declared CSR actions and implementations success. Also the need for effective implementation tools was raised in the literature together with conclusion that the more standards are produced the wider becoming the gap between aspirations of the company and reality of policies adaptation (McCrudden, 2006). The 'production' of corporate Codes of Ethics or colourful sustainability reports, often followed by a growing number of corporate scandals starring with world biggest MNEs, suggest that responsibility could be nothing but simulation 
whereas all those Codes of Ethics, Codes of Conducts and CSR reports become some kind of simulacra of responsibility that is in reality nonexistent (Baudrilliard, 1981).

This study answers to the following research questions: what and how does the headquarters communicate the corporate social responsibility strategy and how do local subsidiaries fulfil these declarations in practice? It focuses on the content of communication on labour-related CSR practices contrasted with their implementation presented from the trade union's perspective in a foreign subsidiary. The paper presents reflection of the research problem in literature, followed by methodological assumptions and results of analysis presented in three consecutive sections i.e. communication on labour in CSR, the effectiveness of CSR policy, and CSR practices analysed from the perspective of social auditors. The final part discusses and concludes the presented results of study analysis as well as indicates the area of further research.

\section{Labour issues in MNEs' strategies in the context of CSR}

The article particularly focuses on the labour perspective as labour is claimed to be a source of competitive advantage and an important internal stakeholder. Moreover, labour especially in the context of access to qualified workforce and labour costs tends to be an important factor determining decisions about investment location (Pournarakis and Varsakelis, 2002). Labour is addressed in almost every CSR standard, but it does not mean that the rights of workers and representing them trade unions are always respected (TUAC, 2016; Daniel et al., 2015). The OECD Guidelines for Multinational Enterprises clearly point that its aim "is to ensure that the operations of these enterprises are in harmony with government policies, to strengthen the basis of mutual confidence between enterprises and the societies in which they operate, to help improve the foreign investment climate and to enhance the contribution to sustainable development made by multinational enterprises” (OECD, 2011, p. 13) and Chapter 5 extensively elaborates on employment and industrial relations in a foreign subsidiary. The norm ISO 26,000 indicates, as core CSR issues, labour practices understood as employment relationship and conditions, human development and training and social dialogue. United Nations Global Compact (UNGC) 
among its 10 principles lists labour including freedom of association and collective bargaining. International Labour Organisation (ILO) Declarations on Principles on Fundamental Rights at Work include one of the principles dedicated to freedom of association and collective bargaining. Finally, the standard dedicated to labour i.e. SA 8,000 is an exhausting catalogue of practices in the area of personnel management and industrial relations.

Literature and empirical research deliver diverse information about approaches to labour and HR issues in MNEs (Marginson, 2016). Some authors point out anti-unions strategies employed by MNEs, stating that neither pay not working hours are the most challenging issues in terms of regime competition but trade union recognition and union avoidance in their foreign subsidiaries (Muller-Camen et al., 2003). As Ferner (1997) argues, the management of MNEs can take two basic approaches i.e. either adapt to the host country environment or create some kind on "cross-national isomorphism" i.e. implement the country of origin patterns in a foreign subsidiary. The author offers also a third way i.e. building their own an internal isomorphism not home or host country patterns but based on its unique character (Ferner, 1997).

The approach to responsible business conduct grows out of the organisational culture and values appreciated by a company. Successful incorporation of social and environmental goals in business operations in a home country does not guarantee the same CSR performance in a host country unit. Some authors claim that the implementation of CSR practices seems to be dependent on distance between host and home countries understood as geographic, culture, economic, and administrative and reflected in differences in regulations, bureaucracy, policies affecting the conditions of employment activities. The authors argue that the bigger distance between home and host countries the weaker enforcement of CSR in foreign subsidiaries. Some explanations may be found in the area of economic and administrative factors, as managers from headquarters will be less attached to CSR activities undertaken in host countries. Moreover, the issue of lower 'return' on investment in CSR associated with host countries tends to determine much more modest budgets allocations for CSR in foreign subsidiaries in comparison to spending on home country CSR arrangements (Campbell et al., 2012). The problem of CSR activities undertaken in foreign subsidiaries especially those located in developing countries has been also explored in previous research with very similar findings 
indicating at lower priority of CSR activities initiated in host countries and diluted CSR interventions in terms of implementation of CSR practices. Moreover, this study also revealed that the CSR activities in foreign subsidiaries mostly were rooted in PR, charity and community actions with very little attention paid to the strategic approach (Jamali, 2010). Noteworthy are also some findings of other empirical research concluding that greater political and legal pressure put on MNEs operating in the EU and development of CSR policies may actually help to comply with labour standards reflected in industrial relations practices at least in some sectors of economy (Van Klaveren et al., 2013).

\section{Methodological assumptions}

The approach to illustration of this single case study is based on the theory of strategy, as practice which is associated with 'doing strategy', and it underlines the importance and meaning of the role of human actors in the processes of putting strategy into practice (Jarzabkowski and Spee, 2009). The qualitative case study (Yin, 2014) was designed to explore the issue of labour in the context of CSR policies conveyed in social communication of a MNE and filtrate them through the perception of workforce of a foreign subsidiary, as well as to capture the potential gap between declarations on CSR strategies and actual implementation practices introduced by a MNE operating in the chemical industry. The presented interpretative study (Creswell, 2013) was designed to answer the research question i.e. what and how do the headquarters communicate the corporate social responsibility strategy and how do local subsidiaries fulfil these declarations in practice? The applied procedure employed a variety of qualitative data collection methods i.e. in depth interviews and observing interviews (Czarniawska, 2014), conducted with workers' representatives in order to understand their perspective on the company's CSR policy. Whereas in order to understand the 'bigger picture' i.e. "the links between micro and macro phenomenon" (Jarzabkowski and Spee, 2009, p. 2), semi structured interviews were conducted with social auditors and CSR consultants, who have had expertise and operational knowledge on implementation of standard SA 8,000 purely dedicated to labour issues in an organisation. Their expertise and social auditing 
experience providing the inside view of the process of implementation of CSR including the SA 8,000 standard in variety companies made their perspective on performance of CSR policies an important point of reference of this study. Moreover the analysis of the documents, materials of the MNE and other study related contents available on the company's website was used. As qualitative nature of study required participation of the variety of individuals including members of the analysed company, their identity required protection and anonymity. Due to sensitive content of the statements given by research participants the name of the company and research participants are not revealed.

The selection of company for this study was based on four determinants i.e. it was (1) a MNE operating in Poland in a special economic zone, in a narrow branch of the chemical industry, as one of the market leaders, (2) declaring compliance with CSR standards, and (3) with trade unions operating within the company. However, the final and decisive factor was (4) an indirect relationship of the local subsidiary with corporate headquarters what was specifically important in the context of study of local performance of global CSR policies.

In terms of company characteristic, this MNE is operating in 150 countries all over the world and was established outside of Europe in early twenties in the last century. The company operates in 28 European countries employing over 12,000 of workers. The first of two Polish plants was founded in 2001. Both of the Polish plants are located in special economic zones benefiting from investment incentives offered by the government. This FDI is quite specific in terms of communication and management, as there is not only relation between home and host countries but also an additional, meta-level i.e. regional key subsidiary unit located in Western Europe. Direct communication between the company headquarters and the Polish subsidiary may be somehow disrupted by an additional actor i.e. the aforementioned key subsidiary.

\section{Communication on labour in CSR}

The results of analysis show asymmetry in information provided by the company headquarters and its Polish subsidiary. Most of information is delivered in English. More details on company CSR activities are available on the regional website but still the global site delivers the richest content. Analysing the content of websites of other MNEs 
operating in the same industry on the Polish market it can be said that the studied case is not isolated. Only one company in this industry, provides general information in the Polish language about its actions and commitments towards sustainable development. However, specific and concrete information can also be accessed only in English. The analysed global company declares variety approaches to social responsibility and sustainable development including respect of human rights and labour practices. The priority areas are: mobility, people and environment, whereas the labour issues are placed under management fundamentals, human rights and labour practices. The approach to responsibility seems to be comprehensive and multifaceted. Furthermore, information about relations with stakeholders, and sustainable/CSR reports can be easily accessed and it is available for downloading. There are detailed information about activities undertaken by the company, however it is difficult to find out what has been done in a particular region. In the case of Poland, there are some actions pointed at the global website, but they seem to be rather ad hoc, social and environmental community actions rather than the examples of strategic CSR as presented in the home country. These activities were not recognized by a representative of the Polish trade union as typical CSR practices but rather as charity and social engagements into local community. However, quite strong identity of a trade union representative with these practices and company was noted.

As mentioned above, although the presence of strong tendency in centralization of information flow about CSR activities implemented in the company has been noted, the regional websites also feed potential viewers with some details about regional CSR engagements. The information is grouped into categories of actions e.g. environmental activities but in order to acquire some detailed information, the viewer is redirected to the global site. Apart from environmental issues, there is information on the approach to procurement, health and safety, stance on human rights, as well as an approach to corporate citizenship. General information is available on the regional website, whereas for details a viewer is redirected to the global site. Interesting seems to be the issue of corporate citizenship. The latter explains, in a comprehensive way, the basic approach of the company to key areas for social activity: safety, environment and issues specific to local communities. The approach is based on three principles: active participation as a member of local community, clarification of the needs of local community 
and work toward solutions, and the last one i.e. ensuring employee participation which is particularly important information from the labour rights viewpoint. In the case of the Polish plant, reported actions are rather charity and volunteering activities. The major weakness noted in the course of analysis of the content of information conveyed through the website lays in the lack of information available in local languages (if different than English) and lack of information on engagement of a particular country i.e. choosing the country in Europe e.g. Germany or Poland the viewer who wants to acquire the information about CSR activities from the German site is automatically redirected to the English information about the CSR in the EU and global actions. Some single examples of engagement of a particular country can be found by more interested and discerning readers. The asymmetry in the information abundance, especially in relation to a home country CSR engagements is visible and it is very difficult to identify what is the plant's approach to CSR.

\section{The effectiveness of CSR policy}

The analysis of recently issued sustainable and CSR reports also did not help to identify the regional and country contribution in implementation of the global CSR strategy. CEO of the group declared the CSR commitments and recognized the role of the company in the globalized world, as well as its social and environmental impact. In terms of stakeholder engagement, employees are recognized as the stakeholder and meeting and communication with labour are stated as responsibility of the company. The sustainability report and information published on the website create an impression of strong commitment to social and environmental goals of the company as a group, but predominant activities are concentrated in Japan - the home country of the MNE. In some parts of the report there is indication of geographical location of performance of a reported activity. Language issues may be a serious obstacle as the Polish plant's workforce does not widely speak English. Another weakness may be observed in a presented approached to communication on CSR with variety stakeholders (including employees), commitment to transparency and conveying on regular basis a solid message on achievements on company's CSR goals. Information that is not available in local languages will not 
address those stakeholders - workers who do not have English language competency. The architecture of information stream is rather difficult to follow. The content of information presented on the website however rich, still does not sufficiently address national developments. This may not have a positive impact on building corporate identity among the workers worldwide and achieving coherence in understanding of the company's development in CSR.

Some gaps between the company's declaration and subsidiaries practices arose also in the context of compliance with the standards especially freedom of association. As freedom of association and collective bargaining have not been explicitly indicated, the recognition of these rights is derived from the company compliance policy. Nonetheless, some positive developments in industrial relations in the period between 2013 and 2016 have been also noted. In 2013, trade unions representatives expressed their frustration concerning lack of dialogue, recognition them as a social partner as well as facing obstruction in carrying out trade union activities. This could be assessed as a typical, aforementioned union avoidance strategy. In 2013, trade union was seeking any solutions that could help to be recognized as a social partner. After three years, workers' representative stated that some improvements in relations with the employer can be noted especially in the context of recognition of trade unions, carrying out trade union activities, following information and consultation rights etc. However, the findings do not allow to assess whether the company decided to respect trade unions rights in accordance with the declared spirit of compliance with the law, standards and regulations or due to recognition of the mobilizing power of trade unions, their capacity to prepare and enter the labour dispute and fear of rising social unrest that might turn into a costly confrontation.

The issue of CSR is claimed to be known by the interviewed trade union, but it was rather associated with charity, volunteering actions and sponsorship. A trade union representative claimed not to be consulted on CSR issues, but the interests in participation in the process of information, consultation and co-determination on CSR activities at their workplace in the future were expressed. However, CSR in the context of labour issues was perceived as manifested through quality employment relations, fair and decent salary in accordance with adequate pay indicators, fair rules of negotiation of the pay scheme especially of the share of performance related pay in total earnings. 


\section{CSR practices in the social auditors' eyes}

The interviews conducted with social auditors and consultants examining the implementation of CSR activities in companies operating on the Polish market have revealed that most frequent motivations for introduction of CSR policies in Poland seem to be the direct pressure from the business partners in the supply chain, willingness to win new business partnership, as well as employer branding, and talent acquisition purposes. The most problematic area would appear to be people management, as auditors stated that CSR in this context appears as "Pandora's box" for some employers, presenting fear from revealing some potential labour law compliance failures. Lack of effective communication at all levels also was pointed out. In some companies where internal communications between workforce and managers at all levels works, as well as communication between the employer and trade unions, the latter tends to play the role of 'agents of changes' in implementation of CSR policies in the area of personnel management. The basic problem in these relations was seen as a weak and invalid communication that did not help to introduce CSR practices or made them malfunctioning. In terms of sectoral developments, it was said that the industries such as automotive, chemical, food processing, and electronics tend to imply a strategic approach to CSR, especially those companies operating in B2B sectors, where pressure for implementation might come from the clients and business partners. Whereas in B2C sectors, the practices are perceived to be based on PR and charity actions rather than a strategic approach to CSR or a sustainable business model. Some of these experiences are covered in the case of the analysed company. In terms of social environment and building the trade union's capacity to use CSR practices for improvement of the quality of work and industrial relations, some national characteristics have been reflected at the company level. Firstly, the use of soft-law e.g. OECD Guidelines was not a common practice, and trade unionists across the country and branches (including the workforce of the studied MNE) have not been familiar with this kind of tools, although, the interests in acquiring knowledge on non-court mechanisms of dispute settlements was in Poland quite high. The typical problem emerging among trade unions in terms of monitoring of their rights at the company level is the language barrier. It appears to have two dimensions. First, the inability to acquire the knowledge about their company as a group, which is 
provided in a foreign language. Secondly, it also seems to be a serious hurdle in terms of horizontal communication with their counterparts in other CEE plants, vertical communication with their counterparts in the company headquarters and /or key subsidiaries, as well as direct communication with the management of the parent company and the key regional subsidiary. This subsequently, may be a significant limitation to build the individual CSR approach as due to lack of English language competency employees cannot learn and imply this approach. As a result, the effectiveness of the CSR strategy at the global level tends to be undermined. Lack of information in the Polish language provided by this MNE is not an isolated case. This practice is still quite popular among MNEs operating in Poland. Communication strategies of MNEs seem not to be adjusted to stakeholders' needs (Piskalski, 2015).

\section{Discussion}

As some authors claim, the success of corporations lies in persistency of a question "what is the corporation and to whom and for what are it and its managers responsible"? (Post et al, 2002). The answer proposed by the authors is worth consideration - as they state "corporations are what they do" (Post et al, 2002, p. 8). There are a few issues that emerge from the study what this particular corporation does. Firstly, the approach of the home country seems to be much more advanced than its foreign subsidiaries, as most information on actions is concentrated on the parent company. Some discrepancy between statement and practice may be noted especially from the Polish labour viewpoint. This may be associated with the style of diffusion of practices in industrial relations and human resource management but also in a way that CSR is approached and communicated. Some discrepancies between declaration and practice from the foreign labour perspective were observed, however, they were followed by further developments.

The asymmetry in quality information on CSR policies implemented in the parent company and foreign subsidiaries also may affect the transparency of the whole group. Another feature is lack of information about CSR activities in the local languages of foreign affiliates. This would appear to be a some kind of the social communication trend observed among MNEs particularly in their foreign subsidiaries. 
Providing extensive information on CSR only in English appears as an insurmountable barrier to MNEs. This subsequently may have a negative impact on the employees' understanding and engagement in the CSR policies worldwide, weakening their global effectiveness and increasing the risk of compliance failure. Reputational risk usually does not affect a single entity but a whole group (Cassin, 2016). Employees are recognized stakeholders and reducing language barrier could be beneficial not only for them but also for the effort of implementation of those policies. Providing the information in languages of local subsidiaries may be in some instances costly but it seems to be essential for elimination the asymmetry in practices presented by a company as well as increasing transparency in reporting the state of developments of CSR from the global perspective. It is difficult to expect that all foreign subsidiaries will report the same level of CSR policy implementation. Apart from a home country strategy, foreign subsidiary policy and know-how, a national approach to CSR may also affect the speed, pace and effectiveness of implementation. However, setting the national, regional goals (encompassing relevance of social and environmental challenges of the foreign subsidiaries) that fit into a global CSR strategy could increase the effectiveness of achievement the CSR vision and make group activities more transparent. There should be a consequence and honesty in communication about CSR activities that would make a single legal entity more accountable. Spreading information about CSR developments that are not applicable to other entity of the group is nothing more than deceiving existing and potential stakeholders and potential investors. Diluted information on the real state of advancement of CSR in foreign subsidiaries does not allow to assess what kind of approach to creation and implementation of CSR strategies has been adopted - standardization, localization or other models of internal isomorphism. What is more, the specific 'conflict' of the concept of standardization versus localization of CSR practices appears to be unsettled. Both approaches offer some convincing arguments. Some authors argue that adaptation of CSR in accordance with local requirements often means decentralization of CSR decision making processes, allowing foreign subsidiaries to create, define and implement their own CSR policies and tools. However, the consistency and coherence with a global strategy requires some coordination and partial centralization of CSR decision making at a group level (Bustamante, 2011). Having in mind a diverse level 
of development of CSR worldwide and complexity of structures and ownership of MNEs, it seems to be useful to build tailored global indicators of CSR development at a group and regional level that allow regional comparative analysis of CSR performance and monitoring of advancement of implementation of the global, coherent socially responsible goals.

Closing the gap between aspirations and reality is needed in order to reduce the social and environmental risks of doing business globally. However, this gap could be reduced by introduction of available, affordable and user friendly tools of implementation and execution of standards. Insufficient social monitoring and exercising of global corporate misconduct not always has been rooted in low capacity of some actors in protecting their rights but also in the lack of clear and coherent indicators that allow verification of companies' CSR declarations versus performance.

\section{Concluding remarks}

The study is not free from limitations. The lack of observations of autonomous dialogue between the employer, managers and trade unions, that could reveal some patterns in organizational behaviours in the area of industrial relations, seems to be one of them. Fruitful would be also the exploration of major competitors of the company under the study operating in Poland that have significant market shares and represent the two other, different countries of origins. It could also interesting to reveal the level of advancement and presence of self-regulatory CSR mechanisms that could also help to build local CSR approaches. Finally, it could also reflect the trade union capacity in use of CSR tools for social monitoring of human and trade union rights at the workplace and their interests in contribution to build more sustainable workplace.

The growing social inequalities and dominance of MNEs put a pressure for shift from the shareholders' to stakeholders' orientation in business. The most colourful reports and mass production of Code of Ethics that do not match the adequate action did not reduce the negative impact of social irresponsibility. The words carefully composed by PR corporate masters in particular social communication channels MUST be adequate to actions and verifiable by company stakeholders. Some scholars argue that if financial performance of companies can 
be objectively assessed and compared by using common tools i.e. balance sheet, income or financial statement, similarly 'sustainability balance sheets and statements' are needed to assess the performance of companies in this area (Montiel and Delgado-Ceballos, 2014). Otherwise we will have subjectively interpreted responsibility and objectively, real and costly social outcomes. It should not be forgotten, that the design of sustainable indicators require more effort, complexity and coherence as those developments are long term in nature (Montiel and Delgado-Ceballos, 2014, p. 21). Therefore, the demand for a new paradigm and a new business model, however well-founded, requires continuous development as it may not be free from practical errors and faults. Thus, further scientific and practitioner exploration for improvement of sustainable business models is needed. Otherwise, colourful CSR reports and codes of ethics will become only symbolic simulacra (Baudrilliard, 1981) of responsibility that in reality does not exist.

\section{References}

Baudrilliard, J. (1981). Simulacra and Simulation. The University Michigan Press.

Bustamante, S. (2011). Localization vs. Standardization: Global Approaches to CSR Management in Multinational Companies (Working Paper No. 60). Berlin School of Economics and Law.

Campbell, J., Eden, L., \& Miller, S. (2012). Multinationals and corporate social responsibility in host countries: Does distance matter? Journal of International Business Studies, 43, 84-106.

Cassin, R. (2016). VW's 14.7 billion US dollars compliance failure: Deal announced to settle U.S. civil emission claims. Retrieved from http://www.fcpablog.com/ blog/2016/6/28/vws-147-billion-compliance-failure-deal-announced-to-settle.html (accessed 28 June 2016).

Creswell, R. J. (2013) Projektowanie badań naukowych: Metody jakościowe, ilościowe i mieszane, Kraków: Wydawnictwo Uniwersytetu Jagiellońskiego.

Czarniawska, B. (2014). Social Science Research: From Field to Desk. London: Sage Publications.

Daniel, C., Wilde-Ramsing, J., Genovese, K., \& Sandjojo, V. (2015). Remedy Remains Rare: An Analysis of 15 Years of NCP Cases and Their Contribution to Improve Access to Remedy for Victims of Corporate Misconduct. Amsterdam: OECD Watch.

Dicken, P. (2003). Global Shift Reshaping the Global Economic Map in the $21^{\text {st }}$ Century. London: Sage Publication.

Enderwick, P. (2005). Attracting “desirable” FDI: Theory and evidence. Transnational Corporations, 14(2), 93-119.

European Commission (2011). Renewed EU Strategy 2011-2014 for Corporate Social Responsibility. Brussels: European Commission. 
Ferner, A. (1997). Country of origin effects and HRM in multinational companies. Human Resource Management Journal, 7(1), 19-37.

Van Klaveren, M., Tijdens, K., \& Gregory, D. (2013). Working in Multinationals and Domestic Firm Compared- Myths and Realities (ETUI Policy Brief No. 1/2013). Brussels.

Jamali, D. (2010), The CSR of MNC subsidiaries in developing countries: Global, local, substantive or diluted? Journal of Business Ethics, 93(2), 181-200.

Jarzabkowski, P., \& Spee, A. P. 2009. Strategy as practice: A review and future directions for the field. International Journal of Management Reviews, 11(1), 69-95.

Marginson, P (2016). Trade Unions and Multinational Companies: A Multi-level Challenge (Warwick Papers in Industrial Relations No. 103). Warwick: The University of Warwick.

McCrudden, Ch. (2006). Corporate Social Responsibility and Public Procurement (Working Paper No 9/2006). University of Oxford.

Montiel, I. \& Delgado-Ceballos, J. (2014). Defining and measuring corporate sustainability: Are we there yet?. Organisation \& Environment, 27(2), 113-139.

Muller-Camen, M., Almond, P., Gunnigle, P., Quintanilla, J., \& Tempel, A. (2003). Between home and host country: Multinationals and employment relations in Europe. Industrial Relations Journal, 32(5), 435-448.

OECD (2011). OECD Guidelines for Multinational Enterprises. Paris: OECD Publishing.

Piskalski, G. (2015). Społeczna odpowiedzialność biznesu w polskich realiach: Teoria a praktyka. Raport z monitoringu społecznej odpowiedzialności największych polskich firm. Warszawa: Fundacja Centrum CSR.PL.

Post, J., Preston, L., \& Sauter-Sachs, S. (2002). Redefining the Corporations: Stakeholder Management and Organizational Wealth. Stanford: Stanford University Press.

Pournarakis, M., \& Varskelis, C. N. (2002). Foreign direct investment in Central and Eastern European Countries: Do institutions matter? Paper presented at the EIBA Annual Conference, December 2002, Athens. Retrieved from http://citeseerx.ist. psu.edu/viewdoc/download?doi=10.1.1.195.993\&rep=rep1\&type=pdf (accessed 14 June 2016).

TUAC (2016). The OECD Guidelines for Multinational Enterprises. Paris: Trade Union Advisory Committee.

Yin, R. K. (2014). Studium przypadku w badaniach naukowych: Projektowanie i metody. Kraków: Wydawnictwo Uniwersytetu Jagiellońskiego. 
